\title{
Microbiological quality of bulk tank raw milk from two dairy farms in Hajdú-Bihar County, Hungary
}

\author{
${ }^{1}$ Benjamin Kojo Woode - ${ }^{1}$ Flóra Mária Petróczki $-{ }^{2}$ Béla Béri $-{ }^{1}$ Ferenc Peles \\ University of Debrecen \\ ${ }^{1}$ Faculty of Agricultural and Food Sciences and Environmental Management, Institute of Food Science, Debrecen, Hungary \\ ${ }^{2}$ Department of Livestock Breeding, Debrecen, Hungary \\ benkojowoode@yahoo.com
}

SUMMARY

Two main channels have been identified to be responsible for microbiological contamination of raw milk and milk products. Firstly, contamination has occurred due to udder infection from the cow or the blood which harbours most bacteria that come in contact with the raw milk. Secondly, via external factors (may include faeces, skin, contaminated water, environment etc.) which are associated with the operation of milking. There is direct contact with the milk and/or surfaces before, during or after the milking, posing public health risk and economic decline. The aim of this study was to examine the bacteriological quality of bulk tank raw milk samples collected from two different size dairy farms (Farm 1 and Farm 2) of different housing forms (cubicle loose and deep litter) in Hajdú-Bihar County, Hungary in July, 2017. Three samples were taken from each farm, and the total plate count, coliform count, Escherichia coli count, Staphylococcus aureus count, and yeast and mould count were determined in them.

The results clearly showed low level of all measured bacteria group load in Farm 1 samples in comparison to Farm 2 with the exception of coagulase-negative Staphylococcus (CNS) which represented high level in general, indicating significant difference $(P<0.05)$. The mean value of total plate count in Farm 2 samples was higher $\left(1.0 \times 10^{5} \mathrm{CFU} / \mathrm{mL}\right)$ than Farm 1 samples $\left(2.8 \times 10^{4} \mathrm{CFU} / \mathrm{mL}\right)$. There was a significant difference $(P<0.05)$ in mean count of coliforms in raw milk samples between Farm 1 and Farm 2. Similarly, results of E. coli were significantly different $(P<0.05)$ with mean count of $1.44 \times 10^{2} \mathrm{CFU} / \mathrm{mL}$ and $2.02 \times 10^{3} \mathrm{CFU} / \mathrm{mL}$ for Farm 1 and Farm 2 respectively. Results of Staphylococcus aureus also showed significant difference $(P<0.05)$ with mean count of $9.7 \times 10^{1}$ CFU/mL for Farm 1 and $6.28 \times$ $10^{2} \mathrm{CFU} / \mathrm{mL}$ for Farm 2. The mean of mould count recorded was $1.07 \times 10^{2} \mathrm{CFU} / \mathrm{mL}$ and $4.93 \times 10^{2} \mathrm{CFU} / \mathrm{mL}$ for Farm 1 and Farm 2 respectively. The recorded mean of yeast count was $1.68 \times 10^{3} \mathrm{CFU} / \mathrm{mL}$ and $3.41 \times 10^{3} \mathrm{CFU} / \mathrm{mL}$ for Farm 1 and Farm 2 respectively; however, both farms showed no significant difference $(P>0.05)$ in terms of mean of mould and yeast count. Although Farm 2 produced six times lower milk quantity than Farm 1, the measured microbial parameters were high. Both farms' microbiological numbers were higher above the permitted limit values as stated by Regulation (EC) No 853/2004, Hungarian Ministry of Health (MoH) 4/1998 (XI. 11.).

This could be an indication of non-conformance to effective GMP, ineffective pre-milking disinfection or udder preparation, poor handling and storage practice, time and temperature abuse and inadequate Food Safety Management System Implementation. Therefore, our recommendation is as follows; establish control measures for pre-and postharvest activities involved in the milking process which would be an effective approach to reduce contamination of the raw milk by pathogenic microorganisms from these farms, strict sanitation regime and hygiene protocol be employed and applied to cows, all equipment, contact surfaces and minimize handling of the milk prior, during and after milking. This will also serve as scientific information to the producers for continual improvement in their operations.

Keywords: bulk tank raw milk, total microbial count, Staphylococcus aureus, CNS, E. coli

\section{INTRODUCTION}

The benefits of unprocessed foods have gained much attention in the world due to enormous health benefits linked with the consumption of raw milk and milk products as well as the taste difference claims by many consumers (Claeys et al. 2013). More so, raw milk has been used in the world as great source of food in one way or the other due to its high nutritive value and it is considered as one of the most important diets among people for over decades and still common in our current generation (Lindmark-Månsson et al. 2003). Further more, surplus of raw milk has been used in the production of other dairy products as a mean to conservation, hence, adding value to the raw material (Guetouache et al. 2014).

In addition to all these benefits derived from raw milk and milk products, numerous researchers have claimed otherwise, demonstrating the adverse health effect of the consumption of raw milk due to the absence of pasteurization. Many claims of outbreak of food borne illness have been associated with the use of raw milk and milk products in our daily diet. Adesiyun et al. (1995) and Soomro et al. (2002), reported on an outbreak involving Listeria monocytogenes, Escherichia coli $\mathrm{O}: 157: \mathrm{H} 7$ being the causative organism for haemolytic and uremic syndrome together with diarrhea and vomiting among children due to the presence of Enteropathogenic $E$. coli strains in raw milk. Rohrbach et al. (1992), also recorded an outbreak by Salmonella spp. in raw milk. Therefore, there is the need for prevention of cross contamination from all likely sources before, during and after the milking process or reduction of these microbial parameters to an acceptable limit to meet the necessary requirement.

The rich composition of raw milk presents a favourable condition for the proliferation of different microorganisms which may affect the milk quality and safety, thereby posing risk to the consumers (Verraes et al. 2015). Furthermore, animal health and personal hygiene are critical to the quality and safety of the raw 
milk because they may also contribute to the introduction of these indicator microorganisms into the raw milk during milking of the cows at the farm level (Bonfoh et al. 2003). Therefore, much is expected of the farm management and employees on the farm to maintain high personal hygiene as well as to follow appropriate procedures to inspect and isolate mastitis cows, clean and disinfect udders and contact surfaces (floor, utensils, etc.) used during the milking of the farm animals (Chey et al. 2004).

According to Mhone et al. (2011), in order to maintain high milk quality there should be in place a proper storage system coupled with an effective hygiene practices throughout the milking operation at the farm level. This practice apparently may be absent on small scale farms and/ or some large scale farms may have a weak food safety systems in place yielding to microbiologically poor quality milk (Chey et al. 2004). Poor milk quality may consequently result in ill health among the consumers especially to infants, young, elderly and those with weak immune system (HIV patients, diabetes patient etc.) and the farmers may also loss a lot more capital should foodborne outbreak occur as a result of consuming raw milk from these farms (Bonfoh et al. 2003).

In this study our aim was to evaluate the bacteriological quality and safety of bulk tank raw milk collected from two different size dairy farms of different housing forms (cubicle loose and deep litter) in the Hajdú-Bihar County, Hungary. The scope of this investigation was limited to the determination of the indicator microorganisms number such as E. coli, coliform, mould and yeast, as well as number of Staphylococcus aureus which is one of the most common pathogen that causes mastitis in cows. We have summarized our preliminary results in this study; but we plan further investigations to better understand the hygienic status of the farms.

\section{MATERIALS AND METHODS}

\section{Place and date of sampling}

The research work was carried out in the microbiology laboratory of the Institute of Food Science, Faculty of Agricultural and Food Sciences and Environmental Management, University of Debrecen, Hungary. Three samples were aseptically collected from two dairy farms in Hajdú-Bihar County (Farm 1 and Farm 2) for this research in July, 2017. There were milked cows from the same breed (Holstein Friesian) with total number of 520-534 and 92 pieces respectively on Farm 1 and Farm 2. Farm 1 produced 14-15,000 liters/day while Farm 2 produced 2.500 liters/day. The cows were housed in cubicle loose in Farm 1 and deep litter in Farm 2. Udder preparation was observed in Farm 1 using water. There was no pre-milking disinfection in Farm 1 but Farm 2 showed pre-milking disinfection. Both farms showed post milking disinfection. The raw milk was stored in the bulk tanks in both farms. Against this background, raw milk samples were tested for total plate count, coliform count, Escherichia coli count, coagulase-positive and coagulase-negative Staphylococcus count, yeast and mould count, to determine the microbiological quality and safety.

\section{Microbiological analysis}

The raw milk samples were prepared under aseptic condition in the microbiological laboratory according to the standard protocol (MSZ EN ISO 6887-1:2000). The milk samples were mixed by shaken gently and the decimal dilutions were prepared.

To enumerate total plate count, the pour plate technique was used. One $\mathrm{ml}$ of the milk samples from appropriate dilutions were transferred into sterile and labelled plastic Petri dishes and then $15-20 \mathrm{ml}$ of preprepared sterile plate count agar (PCA) (Biolab Ltd., Hungary) containing milk powder maintained at $50{ }^{\circ} \mathrm{C}$ in a water bath poured into the sample and shaken thoroughly to mix well. After the agar solidified, the Petri dishes were incubated at $30{ }^{\circ} \mathrm{C}$ for 72 hours in accordance with MSZ EN ISO 4833-1:2014.

The enumeration of coliforms by the pour plate technique, $1 \mathrm{ml}$ of the milk samples from appropriate dilutions were transferred into a sterile and labelled plastic Petri dishes and then 15-20 ml of pre-prepared sterile violet-red-bile-lactose (VRBL) agar (Biolab Ltd., Hungary) maintained at $50{ }^{\circ} \mathrm{C}$ in a water bath poured into the Petri dishes and shaken thoroughly to mix well. After the agar solidified, the Petri dishes were incubated at $37^{\circ} \mathrm{C}$ for 24 hours in accordance with ISO 4832:2006.

To enumerate Escherichia coli by the pour plate technique, $1 \mathrm{ml}$ of the milk samples from appropriate dilutions were transferred into a sterile and labeled plastic Petri dishes and then 15-20 $\mathrm{ml}$ of pre-prepared sterile tryptone-bile-X-glucuronide (TBX) agar (Biolab Ltd., Hungary) maintained at $50{ }^{\circ} \mathrm{C}$ in a water bath poured into the Petri dishes and shaken thoroughly to mix well. After the agar solidified, the Petri dishes were incubated at $37{ }^{\circ} \mathrm{C}$ for $18-24$ hours in accordance with MSZ ISO 16649-2:2005.

Coagulase-positive and coagulase-negative Staphylococcus were enumerated by the spread plate technique, $0.1 \mathrm{ml}$ of the milk samples from appropriate dilutions were spread evenly on the surface of pre-prepared sterile and labelled BairdParker agar media (Biolab Ltd., Hungary), supplemented with sterile egg-yolk tellurite emulsion (LAB-KA Ltd., Hungary). After agar surface drying, the Petri dishes were incubated at $37{ }^{\circ} \mathrm{C}$ for 48 hours in accordance with MSZ EN ISO 6888-1:2008. The identification of $S$. aureus was performed with a latex agglutination test kit (Prolex Staph Xtra Kit, Ferol Ltd., Hungary).

To enumerate yeast and mould colony count using the spread plate technique, $0.1 \mathrm{ml}$ of the milk samples from appropriate dilutions were spread evenly on the surface of prepared sterile and labeled dichloran-rose Bengal-chloramphenicol (DRBC) agar media (VWR International Ltd., Hungary). After the surface of the agar was dry, the Petri dishes were incubated at $25^{\circ} \mathrm{C}$ for 3-5 days in accordance with MSZ ISO 21527$1: 2013$. 


\section{Statistical analysis}

All statistical analyses were performed with SPSS 24.0 (SPSS 2016) to determine the significance of the mean $\Delta$ per specific indicator organism per farm. This was carried out using non-parametric t tests. Mean changes $(\Delta)$ with a $\mathrm{P}$-value of $<0.05$ were considered statistically significant and shown on bar charts.

\section{RESULTS AND DISCUSSION}

In Figure 1 the estimation is shown, the mean of total bacteria were $2.83 \times 10^{4} \mathrm{cfu} / \mathrm{ml}$ and $1.06 \times 10^{5}$ $\mathrm{cfu} / \mathrm{ml}$ on Farm 1 and 2 respectively. There was a significant difference $(\mathrm{P}<0.05)$ between the two farms in the case of total plate count. The mean total plate count (TPC) was above the acceptable limit value $(<100,000 \mathrm{cfu} / \mathrm{ml})$ on Farm 2. This was the evidence of absence of ineffective pre-milking disinfection on Farm 2. This was indicated by poor hygiene related contamination. At the same time, Farm 1 samples were not contaminated due to low count per the limit value as a result of effective pre-milking disinfection before the milking process.

The mean of coliform count showed a significant difference $(\mathrm{P}<0.05)$, recording $2.49 \times 10^{2} \mathrm{cfu} / \mathrm{ml}$ and $2.03 \times 10^{3} \mathrm{cfu} / \mathrm{ml}$ on Farm 1 and 2 respectively (Figure 2). Similarly, there was significant difference between the mean of $E$. coli count of Farm $1(1.44 \times$ $\left.10^{2} \mathrm{cfu} / \mathrm{ml}\right)$ and Farm $2\left(2.02 \times 10^{3} \mathrm{cfu} / \mathrm{ml}\right)$ (Figure 3).

Comparing the mean of coliform counts for both farms to the limit value (m: $10, \mathrm{M}: 100)$, a possible contamination was revealed; however, the presence of coliform alone could not confirm faecal route as the source of contamination of the raw milk samples but can give an indication of poor cleaning practice. Furthermore, the mean of $E$. coli count followed the same trend as the mean of coliform count. The mean of $E$. coli count exceeded the acceptable limit value (m: $<1, \mathrm{M}:<10)$ for both farms. The presence of $E$. coli and coliform gave a confirmation of faecal contamination which may have originated from the cow dung or the hands of the farm workers. This may also have resulted from udder mastitis linked with the presence of E. coli (Worku et al. 2012). The presence of $E$. coli is an indication of a risk that other enteric pathogens may exist (Hayes et al. 2001). The mean of Staphylococcus aureus count also showed as significant difference $(\mathrm{P}<0.05)$ between Farm 1 and Farm $2\left(9.7 \times 10^{1} \mathrm{cfu} / \mathrm{ml}\right.$ and $\left.6.28 \times 10^{2} \mathrm{cfu} / \mathrm{ml}\right)$ respectively (Figure 4). Furthermore, the mean of coagulase-negative Staphylococcus (CNS) count was significantly different $(\mathrm{P}<0.05)$ for the two farms (Figure 5).

Figure 1: Mean of total plate count in raw milk samples collected from Farm 1 and Farm 2

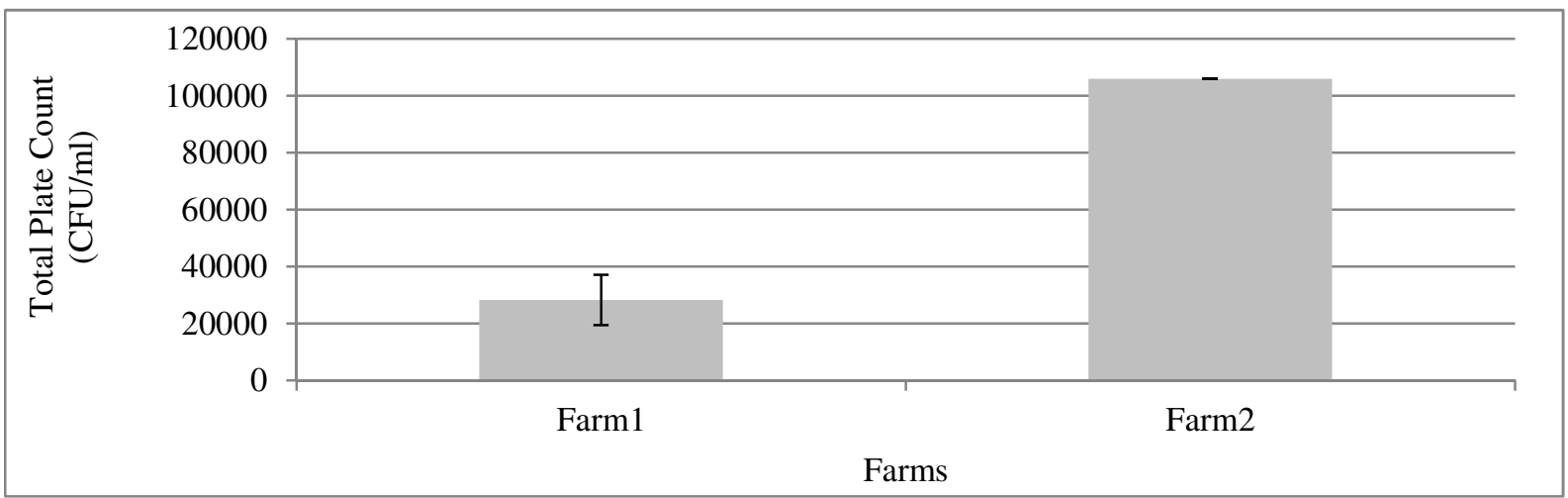

Figure 2: Mean of coliform count in raw milk samples collected from Farm 1 and Farm 2

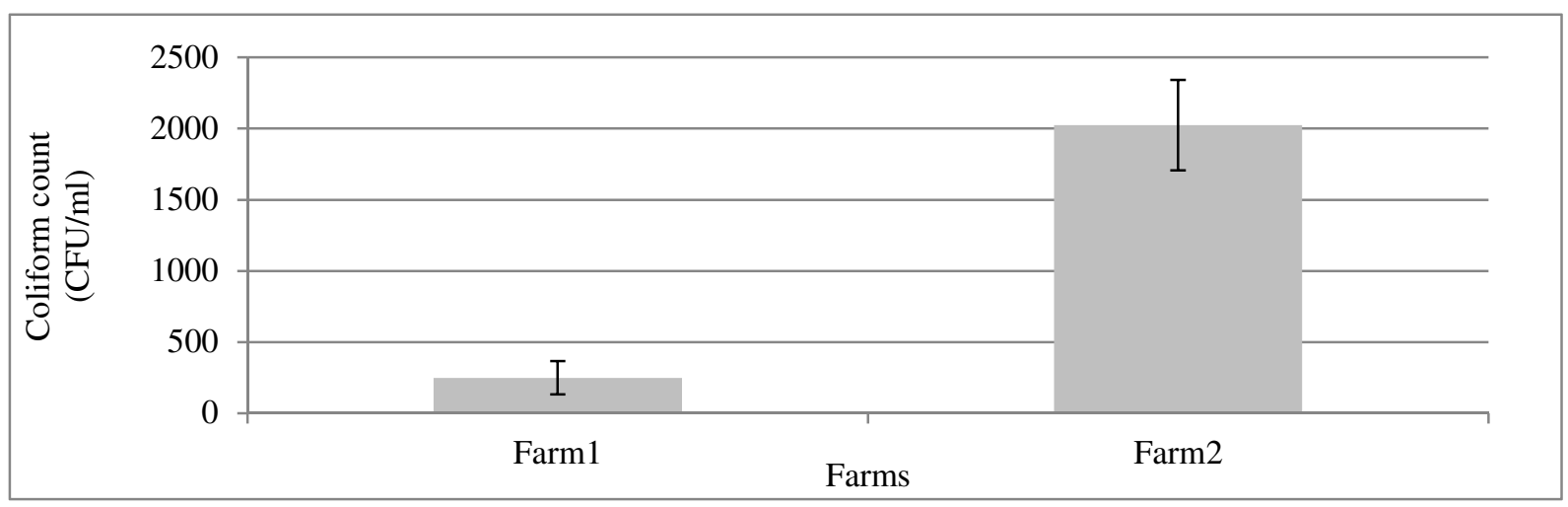


Figure 3: Mean of Escherichia coli count in raw milk samples collected from Farm 1 and Farm 2

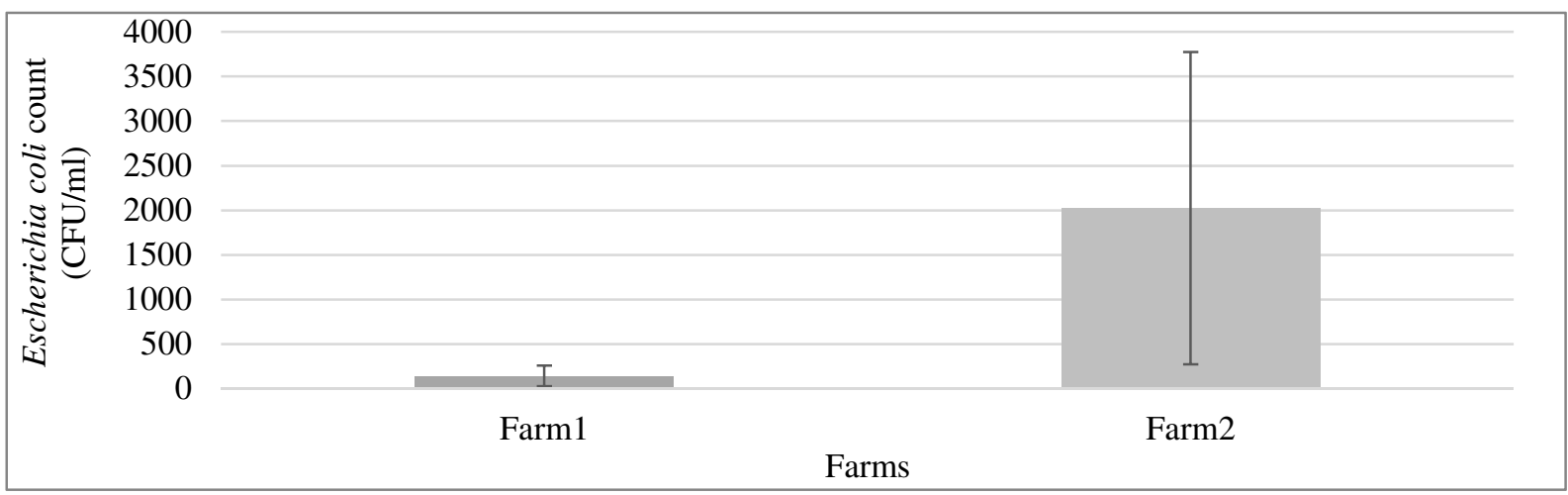

The mean of $S$. aureus count exceeded the limit value (m: 100, M: 500) in the case of Farm 2, which poses a risk to consumers once toxin production is induced under suitable conditions but that of Farm 1 was within the limit value. Peles et al. (2007) found that, the bulk tank milks of 14 out of 20 farms were contaminated with $S$. aureus at levels of up to $6.0 \times$ $10^{3} \mathrm{CFU} / \mathrm{ml}$, and the farm size had no significant effect on the $S$. aureus counts in bulk milk.

On the contrary, on Farm 1, higher value of CNS was recorded compared to Farm 2, however, for CNS toxin production further studies are needed. S. aureus and CNS are known to be responsible for a significant proportion of subclinical and chronic mastitis in dairy cows. Both farms milked the same breeds of cow as mentioned earlier. Therefore, this could confirm that the milked cows in this study were infested with mastitis, however, further study is necessary to be performed to ascertain the breed type and microbial quality. More so, the hands of farm employees might also have contributed to the high level of the $S$. aureus count.

Figure 4: Mean of Staphylococcus aureus count in raw milk samples collected from Farm 1 and Farm 2

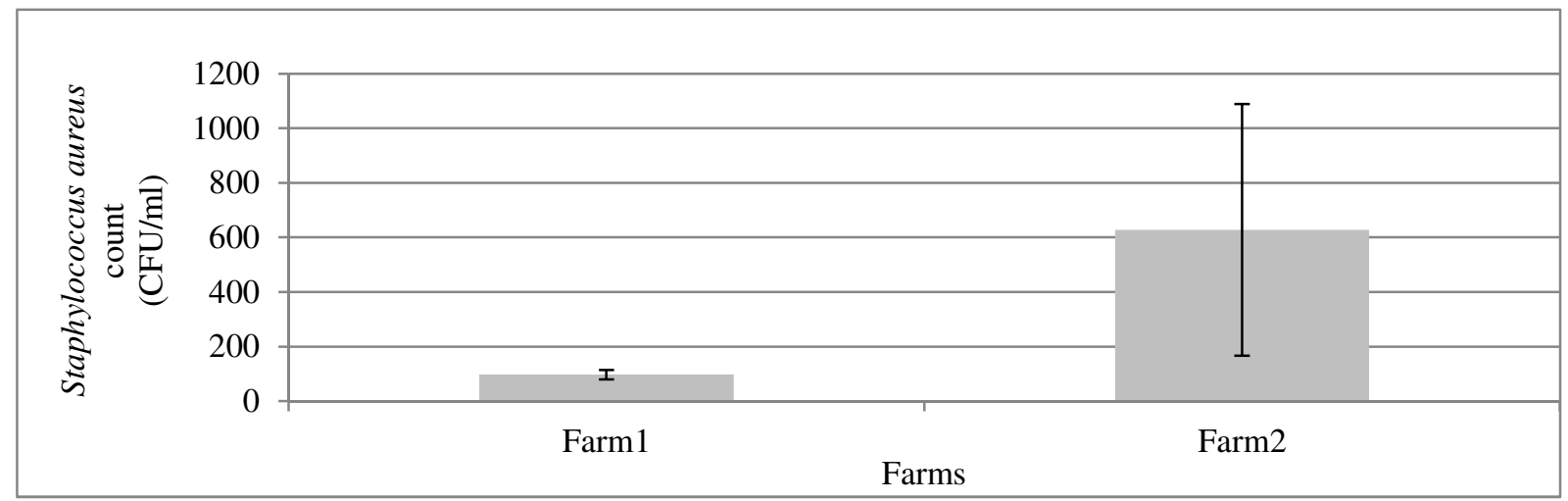

Figure 5: Mean of coagulase-negative Staphylococcus count in raw milk samples collected from Farm 1 and Farm 2

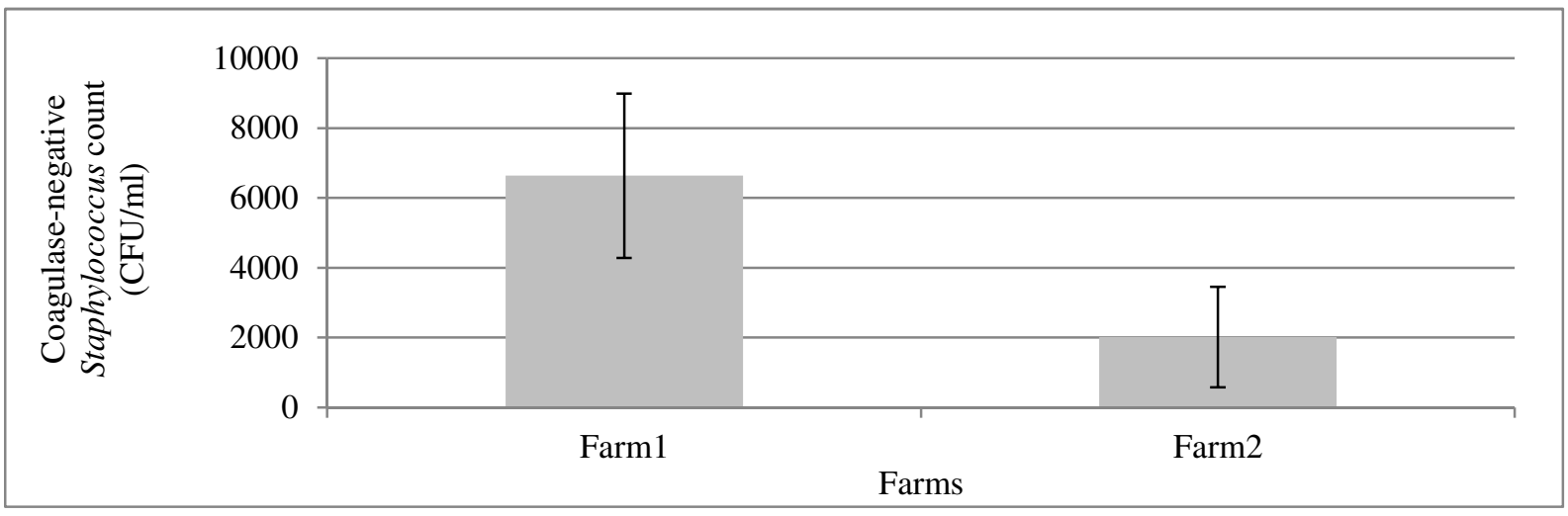


The mean of mould count $\left(1.07 \times 10^{2} \mathrm{cfu} / \mathrm{ml}\right.$ and $4.93 \times 10^{2} \mathrm{cfu} / \mathrm{ml}$ ) for Farm 1 and Farm 2 respectively and mean of yeast count $\left(1.68 \times 10^{3} \mathrm{cfu} / \mathrm{ml}\right.$ and $3.41 \times$ $10^{3} \mathrm{cfu} / \mathrm{ml}$ ) for Farm 1 and Farm 2 respectively indicated no significant difference $(\mathrm{P}>0.05)$ as shown in Figure 6 and in Figure 7. Some level of mould and yeast were recorded in the samples under this study. The presence of yeast and mould recorded may be due to contact of the milk with animal feed as well as environment and the air around the milking area. The deep litter housing of Farm 2 cows could have increase the mould and yeast count since the herds have direct contact and sleep in the straw. Conversely, Farm 1 use cubicle loose housing, where only the head could access the straw.

Figure 6: Mean of mould count in raw milk samples collected from Farm 1 and Farm 2

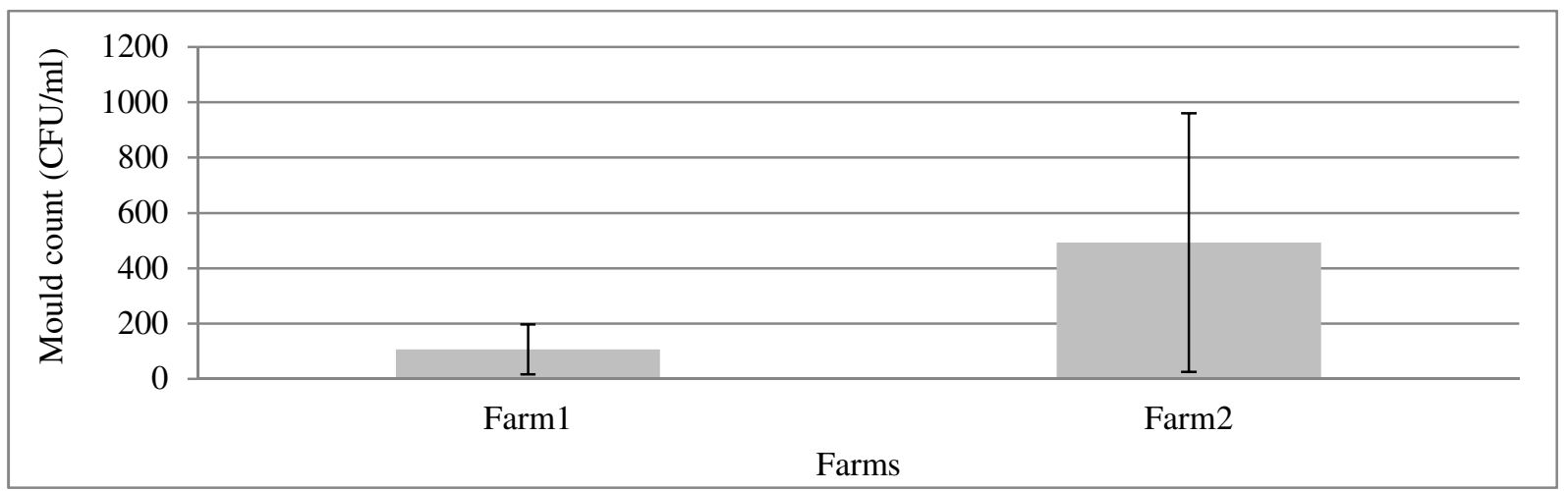

Figure 7: Mean of yeast count in raw milk samples collected from Farm 1 and Farm 2

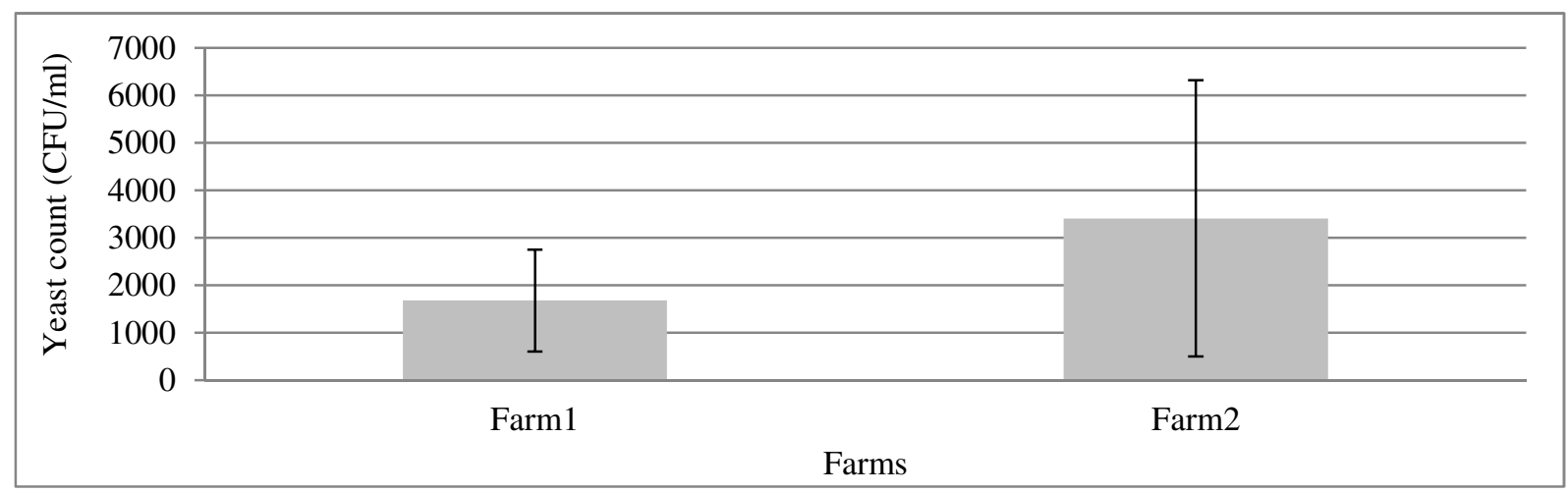

The cleaning and disinfection of cow udders before milking is an important step in the milking process since there is the likelihood of direct contact with the ground, urine, dung and feed residues while resting. In consideration of the mean counts of the microbial parameters analyzed in this study gave a remarkable picture and a clear indication of microbiological contamination as far as both farms are concerned. Although the mode of storage of the raw milk in these two farms was the recommended storage system, it was critical for the farm operators to ensure effective implementation of control measures implemented at all the steps of milk production prior to storage. Anything contrary to this was certain to have compromised on the quality and safety of the raw milk produced in these farms. Subsequently, once cleaning is not properly done, the milk residues that remain on utensils used in the milking process provide essential nutrients for the growth of these bacteria which in effect affect successive batches of milk produced.
The total plate count enumeration method is the most commonly used in the milk processing industry to assess the hygienic state of raw milk, hence an important indicator of hygienic conditions before, during and after milking at farm level. Farm 2 recorded high TPC counts $\left(1.06 \times 10^{5} \mathrm{cfu} / \mathrm{ml}\right)$ in this study as compared to the limit value but Farm 1 recorded lower than the limit value $\left(2.83 \times 10^{4} \mathrm{cfu} / \mathrm{ml}\right)$. Millogo et al. (2010) indicated that to avoid contamination of milk after milking, requires an abrupt attention to the cleaning procedures during milking, cleaning of milking equipment and hygienic handling of the milk. Poor cleaning of containers and storage tanks leaves milk with residual contamination level of $1.26 \times 10^{4} \mathrm{cfu} / \mathrm{ml}$ (Bonfoh et al. 2006). Reasoning from this fact, the TPC counts recorded in this study revealed that Farm 2 had deficiencies in their cleaning and sanitation regimes.

The mean of coliform counts enumerated from Farm 1 and Farm 2 milk samples also established an evidence of the poor sanitary conditions. According to 
Bramley and McKinnon (1990) coliform microorganisms are found also on the surface of the under shed or moist milking equipment. Isolated cases of high coliform counts may also be a result of unidentified coliform mastitis, which is mostly caused by the presence of $E$. coli (Worku et al. 2012).

Owning to this assertion, the mean of E. coli counts in the raw milk samples enumerated could be a possible indication of mastitis infection among the milked cows as the values from both farms were way high above the tolerable limit by the Hungarian Ministry of Health (MoH) 4/1998 (XI. 11.) requirement hence may pose health risk. It is an established fact that mastitis udder contribute to poor microbiological quality raw milk if not brought under strict control (O'Brien et al. 2009). Hayes et al. (2001) also reported that the presence of $E$. coli is an indication of a risk that other enteric pathogens may exist (Hayes et al. 2001).

The mean of Staphylococcus aureus count in Farm 1 samples was below the limit value but the mean of Staphylococcus aureus count was relatively high above the tolerable limits in samples on Farm 2. The surfaces of animals, udder and teat canals are likely contamination source of Staphylococcus aureus in raw milk. Both $S$. aureus and CNS are known to be responsible for a significant proportion of subclinical and chronic mastitis in dairy cows. Another likely source of $S$. aureus in the milk samples could be from the hands of dairy workers and food handlers as reported by Kamal et al. (2013). Therefore, poor personal hygiene practices may have contributed to this high counts in the milk samples on Farm 2.

Godič and Teger (2008) reported mean number of yeasts and moulds in raw milk samples as $2.00 \times 10^{2}$ $\mathrm{cfu} / \mathrm{ml}$ whereas Fadda et al. (2004) recorded mean yeast count $\left(3.98 \times 10^{2} \mathrm{cfu} / \mathrm{ml}\right)$ in raw milk from farms located in different areas of Sardinia. McManus and Lanier (1987), reiterated that there occurs very neglegible numbers of yeast in raw milk owning to presence of psychrotrophic bacteria that compete for the growth substrates or owing to inhibition by metabolites excreted by bacteria but the means of yeast counts in our study was comparatively higher than the values indicated by these researchers.

Godič and Teger (2008), confirmed the claim made by O'Brien et al. (2005), that about $91 \%$ of baled grass silage contaminated with mould could contaminate raw milk and were actually present in the raw milk samples analyzed for their study, hence, stated that it could be likely that one of the conceivable sources of raw milk contamination was the feed. In addition many conceivable sources of mould and yeast contamination of raw milk beside the feed also could be the environment and the air. Godič and Teger (2008), anticipated higher number of yeasts and mould in sampled milk in winter since the pasture or the hay was replaced by conserved or ensiled feed but unexpectedly, the mean number of yeasts and mould in summer raw milk samples were a little higher $\left(3.16 \times 10^{2} \mathrm{cfu} / \mathrm{ml}\right)$ than that in winter $(1.58 \times$ $\left.10^{2} \mathrm{cfu} / \mathrm{ml}\right)$. Our study also confirmed the summer values of the research above, as it revealed higher mould and yeast count in samples from both Farm 1 and Farm 2.

\section{CONCLUSION}

The bulk tank raw milk samples from these two farms used for this study revealed poor microbiological quality and safety. The raw milk samples showed average contamination against the standard limit values for the enumerated microbial parameters. The sources of this microbiological contamination may have included but not limited to the ineffectiveness of the pre-milking disinfection and cow udder preparation prior to milking process. Again, the cows used for milking needs proper health management in accordance with Good Agricultural Practice (GAP).

The deep litter housing system exposes the cows to cow dung and feed which harbour most of these bacteria under investigation which implies that there is the possibility of contamination if proper sanitation is not ensured prior to milking of these cows. Additionally, cubicle loose housing system puts a limitation to the level of contact the cows have with their feed and waste, thereby, reducing the chances of contaminating the raw milk. Comparatively, the deep litter housing may have contributed to the high number of measure microbes in the samples from Farm 1 compared to that of Farm 2. Furthermore, handling and storage is critical to the safety of the raw milk, therefore poor handling as well as time and temperature abuse contributed to the poor microbiological quality of the samples analyzed.

The presences of Staphylococcus aureus poses public health risk if proper measures are not laid down to find corrective action to this problem, whereas the presence of $E$. coli is an indication of the existence of safety risk due to its association with pathogenic enterobacteria. Once the raw milk from these farms are consumed unpasteurized, a number of people would be found with infections and many others hospitalized due to the presence of the enumerated bacteria in the raw milk from Farm 1 and Farm 2. If we consider most of the foodborne outbreaks, most of the bacteria involved were isolated from products made from suspected contaminated raw milk or sources similar to that encountered in our study. Producers of dairy product(s) then need to demonstrate a very high level of commitment to ensuring that raw milk of such poor quality and safety do not enter the food chain for further processing. It is very important then that control measures for pre and postharvest activities involved in milking process which would be an effective approach to reduce pathogenic contamination in the raw milk at the farm level be established.

To bring such situation under control, the farm operators must also ensure strict sanitation, good hygiene practices and effective food safety system is implemented and enforced at the farm level until the final destination, regular swab analysis should be 
conducted on contact surfaces as well as regular health check on cows and employees who come in contact with the raw milk and its handling. Storage time and temperature are also critical to the microbiological quality of the raw milk. Due to the obtained findings, appropriate risk communication on the consumption of raw milk, targeting and enhancing education for the vulnerable population are recommended. Moreover, training of persons involved in the milking process, handling, storage and transporting is crucial to the microbiological quality of the raw milk.

\section{ACKNOWLEDGEMENTS}

The work/publication is supported by the EFOP3.6.3-VEKOP-16-2017-00008 project. The project is co-financed by the European Union and the European Social Fund.

\section{REFERENCES}

4/1998 (XI 11) regulation of the Hungarian Ministry of Health.

Adesiyun, A. A.-Webb, L.-Rahaman, S. (1995): Microbiological quality of raw cow's milk at collection centers in Trinidad. Journal of Food Protection. 58. 2: 139-146.

Bonfoh, B.-Wasem, A.-Traore, A. N.-Fane, A.-Spillmann, H.Simbe, C. F.-Alfaroukh, I. O.-Nicolet, J.-Farah, Z.-Zinsstag, J. (2003): Microbiological quality of cows' milk taken at different intervals from the udder to the selling point in Bamako (Mali). Food Control. 14. 7: 495-500.

Bonfoh, B.-Roth, C.-Traore, N.-Fane, A.-Simbe, C. F.Alfaroukhd, I. O.-Nicolete, J.-Farahb, Z.-Zinsstaga, J. (2006): Effect of washing and disinfecting containers on the microbiological quality of fresh milk sold in Bamako (Mali). Food Control. 17. 2: 153-161.

Bramley, J.-McKinnon, H. (1990): Microbiology of Raw Milk. London-New York. Elsevier Applied Science. 171.

Chey, F. Y.-Abdyllah, A.-Ayob, L. (2004): Bacteriological quality and safety of raw milk in Malaysia. Food Microbiology. 21. 5: 535-554.

Claeys, W. L.-Cardoen, S.-Daube, G. (2013): Raw or heated cow milk consumption: review of risks and benefits. Food Control. 31. 1: 251-262.

European Commission (2004): Corrigendum to Regulation (EC) No $853 / 2004$ of the European Parliament and of the Council of 29 April 2004: Laying Down Specific Hygiene Rules for Food of Animal Origin. 51.

Fadda, M. E.-Mossa, V.-Pisano, M. B.-Deplano, M.-Cosentino, S. (2004): Occurence and characterization of yeasts isolated from artisanal Fiore Sardo cheese. International Journal of Food Microbiology. 95. 1: 51-59.

Godič, K.-Teger, S. (2008): Microbiological quality of raw milk after introducing the two day's milk collecting system. Acta agriculturae Slovenica. 92. 1: 61-74.

Guetouache, M.-Bettache, G.-Samir, M. (2014): Composition and nutritional value of raw milk. Biological Sciences and Pharmaceutical Research. 2. 10: 115-122.

Hayes, M. C.-Ralyea, R. D.-Murphy, S. C.-Carey, N. R.-Scarlett, J. M.-Boor, K. J. (2001): Identification and characterization of elevated microbialcounts in bulk tank raw milk. Journal of Dairy Science. 84. 1: 292-298.

ISO 4832 (2006): Microbiology of food and animal feeding stuffs - Horizontal method for the enumeration of coliforms.

Kamal, R. M.-Bayoumi, M. A.-Abd El Aal, S. F. A. (2013): MRSA detection in raw milk, some dairy products and hands of dairy workers in Egypt, a mini-survey. Food Control. 33. 1: 49-53.

Lindmark-Månsson, H.-Fonden, R.-Erik-Pettersson, H. (2003): Composition of Swedish Dairy Milk. International Journal of Dairy Technology. 13. 6: 409-425.
McManus, C.-Lanier, J. M. (1987): Salmonella, Campylobacter jejuni, and Yersinia enterocolitica in raw milk. Journal of Food Protection. 50. 1: 51-55.

Mhone, T. A.-Matope, G.-Saidi, P. T. (2011): Aerobic bacterial, coliform, Escherichia coli and Staphylococcus aureus counts of raw and processed milk from selected smallholder dairy farms of Zimbabwe. International Journal of Food Microbiology. 151. 2: 223-228.

Millogo, V.-Sjaunja, S.-Ouedraogo, A.-Agenas, S. (2010): Raw milk hygiene at farms, processing units and local markets in Burkina Faso. Food Control. 21. 7: 1070-1074.

MSZ EN ISO 6887-1 (2000): Microbiology of food and animal feeding stuffs - Preparation of test samples, initial suspension and decimal dilutions for microbiological examination.

MSZ EN ISO 6888-1 (2008): Microbiology of food and animal feeding stuffs - Horizontal method for the enumeration of coagulase-positive staphylococci (Staphylococcus aureus and other species) Technique using Baird-Parker agar medium.

MSZ EN ISO 4833-1 (2014): Microbiology of the food chain Horizontal method for the enumeration of microorganisms Part 1: Colony count at 30 degree $\mathrm{C}$ by the pour plate technique.

MSZ ISO 16649-2 (2005): Microbiology of food and animal feeding stuffs - Horizontal method for the enumeration of betaglucuronidase-positive Escherichia coli.

MSZ ISO 21527-1 (2013): Microbiology of food and animal feeding stuffs - Horizontal method for the enumeration of yeasts and moulds.

O'Brien, M.-O'Kiely, P.-Forristal, P. D.-Fuller, H. T. (2005): Fungi isolated from contaminated baled grass silage on farms in the Irish Midlands. FEMS Microbiological Letters. 247. 2: 131-135.

O’Brien, B.-Berry, D. P.-Meaney, W. J.-O'Callaghan, E. J. (2009): A study of the somatic cell count (SCC) of Irish milk from herd management and Environmental perspectives, Moorepark Dairy Production Research Centre. 23.

Peles, F.-Wagner, M.-Varga, L.-Hein, I.-Rieck, P.-Gutser, K.Keresztúri, P.-Kardos, G.-Turcsányi, I.-Béri, B.-Szabó, A. (2007): Characterization of Staphylococcus aureus strains isolated from bovine milk in Hungary. International Journal of Food Microbiology. 118. 2: 186-193.

Rohrbach, B. W.-Draughon, F. A.-Davidson, P. M.-Oliver, S. P. (1992): Prevalence of Listeria monocytogenes, Campylobacter jejuni, Yersinia enterocolitica and Salmonella in bulk tank milk: risk factors and risk of human exposure. Journal of Food Protection. 55. 2: 93-97.

Soomro, A. H.-Arain, M. A.-Khaskheli, M.-Bhutto, B. (2002): Isolation of Escherichia coli from raw milk and milk products in relation to public health sold under market conditions at Tandojam. Pakistan Journal of Nutrition. 1. 3: 151-152. 
SPSS (2016): SPSS 24.0 for Windows. SPSS Inc. Chicago. IL. USA. Copyright @ SPSS Inc. 1989--2016.

Verraes, C.-Vlaemynck, G.-Van Weyenberg, S.-De Zutter, L.Daube, G.-Sindic, M.-Uyttendaele, M.-Herman, L. (2015): A review of the microbiological hazards of dairy products made from raw milk. International Dairy Journal. 50: 32-44.
Worku, T.-Negera, E.-Nurfeta, A.-Welearegay, H. (2012): Microbiological quality and safety of raw milk collected from Borana pastoral community, Oromia Regional State. African Journal of Food Science and Technology. 3. 9: 213-222. 